\title{
Front Matter: Volume 8076
}

, "Front Matter: Volume 8076," Proc. SPIE 8076, EUV and X-Ray Optics: Synergy between Laboratory and Space II, 807601 (3 June 2011); doi: 10.1117/12.901322

SPIE. Event: SPIE Optics + Optoelectronics, 2011, Prague, Czech Republic 


\title{
PROCEEDINGS OF SPIE
}

\section{EUV and X-Ray Optics: Synergy between Laboratory and Space II}

\author{
René Hudec \\ Ladislav Pina \\ Editors
}

20-21 April 2011

Prague, Czech Republic

Sponsored and Published by

SPIE

Cooperating Organisations

ELI Beamlines

HiPER 
The papers included in this volume were part of the technical conference cited on the cover and title page. Papers were selected and subject to review by the editors and conference program committee. Some conference presentations may not be available for publication. The papers published in these proceedings reflect the work and thoughts of the authors and are published herein as submitted. The publisher is not responsible for the validity of the information or for any outcomes resulting from reliance thereon.

Please use the following format to cite material from this book:

Author(s), "Title of Paper," in EUV and X-Ray Optics: Synergy between Laboratory and Space II, edited by René Hudec, Ladislav Pina, Proceedings of SPIE Vol. 8076 (SPIE, Bellingham, WA, 2011) Article CID Number.

ISSN 0277-786X

ISBN 9780819486660

Published by

SPIE

P.O. Box 10, Bellingham, Washington 98227-0010 USA

Telephone +1 3606763290 (Pacific Time) · Fax +1 3606471445

SPIE.org

Copyright (C) 2011, Society of Photo-Optical Instrumentation Engineers

Copying of material in this book for internal or personal use, or for the internal or personal use of specific clients, beyond the fair use provisions granted by the U.S. Copyright Law is authorized by SPIE subject to payment of copying fees. The Transactional Reporting Service base fee for this volume is $\$ 18.00$ per article (or portion thereof), which should be paid directly to the Copyright Clearance Center (CCC), 222 Rosewood Drive, Danvers, MA 01923. Payment may also be made electronically through CCC Online at copyright.com. Other copying for republication, resale, advertising or promotion, or any form of systematic or multiple reproduction of any material in this book is prohibited except with permission in writing from the publisher. The CCC fee code is 0277-786X/11/ \$18.00.

Printed in the United States of America.

Publication of record for individual papers is online in the SPIE Digital Library.

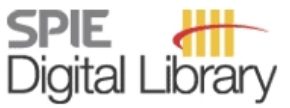

SPIEDigitalLibrary.org

Paper Numbering: Proceedings of SPIE follow an e-First publication model, with papers published first online and then in print and on CD-ROM. Papers are published as they are submitted and meet publication criteria. A unique, consistent, permanent citation identifier (CID) number is assigned to each article at the time of the first publication. Utilization of CIDs allows articles to be fully citable as soon as they are published online, and connects the same identifier to all online, print, and electronic versions of the publication. SPIE uses a six-digit CID article numbering system in which:

- The first four digits correspond to the SPIE volume number.

- The last two digits indicate publication order within the volume using a Base 36 numbering system employing both numerals and letters. These two-number sets start with $00,01,02,03,04$, $05,06,07,08,09,0 A, 0 B \ldots 0 Z$, followed by 10-1Z, 20-2Z, etc.

The CID number appears on each page of the manuscript. The complete citation is used on the first page, and an abbreviated version on subsequent pages. Numbers in the index correspond to the last two digits of the six-digit CID number. 


\section{Contents}

vii Conference Committee
ix Introduction

SESSION 1 ASTRONOMICAL X-RAY OPTICS I

807602 Lightweight and high angular resolution x-ray optics for astronomy (Invited Paper) [8076-01] W. W. Zhang, NASA Goddard Space Flight Ctr. (United States)

807603 Compact optics for high resolution spectroscopy of celestial x-ray sources [8076-02] W. Cash, Univ. of Colorado at Boulder (United States); C. Lillie, Northrop Grumman Aerospace Systems (United States); R. McEntaffer, Univ. of lowa (United States); W. Zhang, NASA Goddard Space Flight Ctr. (United States)

807604 Extremely lightweight $x$-ray optics based on thin substrates [8076-03] R. Hudec, Astronomical Institute, ASCR (Czech Republic) and Czech Technical Univ. (Czech Republic); J. Sik, M. Lorenc, ON Semiconductor Czech Republic (Czech Republic); L. Pina, Czech Technical Univ. (Czech Republic); V. Marsikova, Rigaku Innovative Technologies Europe (Czech Republic); M. Mika, Institute of Chemical Technology (Czech Republic); A. Inneman, Rigaku Innovative Technologies Europe (Czech Republic); M. Skulinova, Astronomical Institute, ASCR (Czech Republic)

807605 Deformable mirrors for x-ray astronomy and beyond [8076-04]

M. P. Ulmer, M. E. Graham, S. Vaynman, J. Cao, Northwestern Univ. (United States);

P. Z. Takacs, Brookhaven National Lab. (United States)

807606 Technologies for manufacturing of high angular resolution multilayer coated optics for the New Hard X-ray Mission [8076-05]

A. Orlandi, Media Lario Technologies (Italy); S. Basso, INAF, Osservatorio Astronomico di Brera (Italy); G. Borghi, R. Binda, Media Lario Technologies (Italy); O. Citterio, Media Lario Technologies (Italy) and INAF, Brera Astronomical Observatory (Italy); G. Grisoni, J. Kools, F. Marioni, N. Missaglia, Media Lario Technologies (Italy); B. Negri, Agenzia Spaziale Italiana (Italy); R. Negri, G. Pareschi, INAF, Osservatorio Astronomico di Brera (Italy); L. Raimondi, INAF, Osservatorio Astronomico di Brera (Italy) and Univ. dell' Insubria (Italy); A. Ritucci, Media Lario Technologies (Italy); B. Salmaso, G. Sironi, D. Spiga, INAF, Osservatorio Astronomico di Brera (Italy); R. Subranni, Media Lario Technologies (Italy); G. Tagliaferri, INAF, Osservatorio Astronomico di Brera (Italy); G. Valsecchi, D. Vernani, Media Lario Technologies (Italy)

\section{SESSION 2 ASTRONOMICAL X-RAY OPTICS II}

$807607 \quad$ Kirkpatrick-Baez x-ray optics: a review (Invited Paper) [8076-06]

R. Hudec, Astronomical Institute, ASCR (Czech Republic) and Czech Technical Univ. in Prague (Czech Republic) 
807608 Innovative multilayer coatings for space solar physics: performances and stability over time (Invited Paper) [8076-07]

P. Zuppella, A. J. Corso, P. Nicolosi, Institute for Photonics and Nanotechnologies, CNR (Italy) and Univ. degli Studi di Padova (Italy); D. L. Windt, Reflective X-Ray Optics LLC (United States); M. G. Pelizzo, Institute for Photonics and Nanotechnologies, CNR (Italy) and Univ. degli Studi di Padova (Italy)

807609 Full-aperture x-ray tests of Kirkpatrick-Baez modules: preliminary results [8076-08] L. Pina, Rigaku Innovative Technologies Europe (Czech Republic) and Czech Technical Univ. in Prague (Czech Republic); V. Marsikova, Rigaku Innovative Technologies Europe (Czech Republic); R. Hudec, Czech Technical Univ. in Prague (Czech Republic) and Astronomical Institute, ASCR (Czech Republic); A. Inneman, J. Marsik, Rigaku Innovative Technologies Europe (Czech Republic); W. Cash, A. Shipley, B. Zeiger, Univ. of Colorado at Boulder (United States)

8076 OA The mirror module design for the cryogenic x-ray imaging spectrometer on-board ORIGIN [8076-09]

M. Barbera, Univ. degli Studi di Palermo (Italy) and INAF-Osservatorio Astronomico di Palermo Giuseppe S. Vaiana (Italy); T. Mineo, INAF-IASF Palermo (Italy); S. Basso,

INAF-Osservatorio Astronomico di Brera (Italy); F. E. Christensen, Danish National Space Ctr. (Denmark); J.-W. den Herder, J. Kaastra, SRON Nationaal Instituut voor Ruimteonderzoek (Netherlands); L. Piro, INAF-IASF Roma (Italy); D. Spiga, INAF-Osservatorio Astronomico di Brera (Italy); C. van Baren, SRON Nationaal Instituut voor Ruimteonderzoek (Netherlands)

8076 OB Optical subsystem characterization in laboratory [8076-10]

P. Nicolosi, P. Zuppella, A. J. Corso, Institute for Photonics and Nanotechnologies, CNR (Italy) and Univ. degli Studi di Padova (Italy); V. Polito, Institute for Photonics and Nanotechnologies, CNR (Italy); M. G. Pelizzo, Institute for Photonics and Nanotechnologies, CNR (Italy) and Univ. degli Studi di Padova (Italy); J. F. Mariscal, N. Rouanet, P. O. Mine, E. Quémerais, J. L. Maria, Lab. Atmosphères, Milieux, Observations Spatiales, CNES (France)

8076 OC Lobster eye optics for nano-satellite x-ray monitor [8076-11]

V. Tichý, Czech Technical Univ. in Prague (Czech Republic); M. Barbera, Univ. degli Studi di Palermo (Italy) and INAF, Osservatorio Astronomico di Palermo (Italy); A. Collura, Osservatorio Astronomico di Palermo (Italy); M. Hromčík, Czech Technical Univ. in Prague (Czech Republic); R. Hudec, Astronomical Institute, ASCR (Czech Republic) and Czech Technical Univ. in Prague (Czech Republic); A. Inneman, Rigaku Innovative Technologies Europe (Czech Republic); J. Maršík, Czech Technical Univ. in Prague (Czech Republic); V. Maršíková, Rigaku Innovative Technologies Europe (Czech Republic); L. Pína, Czech Technical Univ. in Prague (Czech Republic); V. Šimon, Astronomical Institute, ASCR (Czech Republic); S. Varisco, Osservatorio Astronomico di Palermo (Italy)

\section{SESSION 3 LABORATORY MULTI-LAYER X-RAY AND EUV OPTICS}

8076 OD Multilayer coatings for the far and extreme ultraviolet (Invited Paper) [8076-12] J. I. Larruquert, M. Vidal-Dasilva, S. García-Cortés, L. Rodríguez-de Marcos, M. Fernández-Perea, J. A. Aznárez, J. A. Méndez, Consejo Superior de Investigaciones Científicas (Spain) 
8076 OF Multilayer-coated micro-grating array for x-ray phase-contrast imaging [8076-14] S. K. Lynch, National Heart, Lung and Blood Institute, National Institutes of Health (United States); C. Liu, L. Assoufid, Argonne National Lab. (United States); N. Y. Morgan, National Institute of Biomedical Imaging and Bioengineering, National Institutes of Health (United States); D. Mazilu, E. Bennett, C. K. Kemble, H. H. Wen, National Heart, Lung and Blood Institute, National Institutes of Health (United States)

8076 OG Experimental investigations of backward transition radiation characteristics in extreme ultraviolet region [8076-15]

L. G. Sukhikh, Deutsches Elektronen-Synchrotron (Germany) and Tomsk Polytechnic Univ. (Russian Federation); D. Krambrich, Johannes Gutenberg Univ. Mainz (Germany); G. Kube, Deutsches Elektronen-Synchrotron (Germany); W. Lauth, Johannes Gutenberg Univ. Mainz (Germany); Yu. A. Popov, A. P. Potylitsyn, Tomsk Polytechnic Univ. (Russian Federation)

\section{SESSION $4 \quad$ X-RAY REFRACTIVE OPTICS AND MICROSCOPY}

8076 Ol Advances in the development of $x$-ray refractive large aperture rolled prism lenses [8076-17]

H. Vogt, Karlsruher Institut für Technologie (Germany); R. Eisenhower, Bruker AXS GmbH (Germany); A. Last, Karlsruher Institut für Technologie (Germany); K. U. Mettendorf, Bruker AXS GmbH (Germany); J. Mohr, V. Nazmov, M. Simon, Karlsruher Institut für Technologie (Germany)

\section{SESSION 5 EUV OPTICS AND SOURCES, MICROLITHOGRAPHY OPTICS}

8076 OK Time resolved EUV pump-probe microscopy of fs-LASER induced nanostructure formation [8076-19]

R. Freiberger, J. Hauck, M. Reininghaus, D. Wortmann, L. Juschkin, RWTH Aachen Univ. (Germany)

8076 OL Measurement of characteristics of a XUV capillary laser [8076-20] J. Novak, M. Nevrkla, A. Jancarek, Czech Technical Univ. in Prague (Czech Republic)

8076 OM Problem of roughness detection for supersmooth surfaces [8076-21] M. M. Barysheva, B. A. Gribkov, Yu. A. Vainer, M. V. Zorina, A. E. Pestov, Institute for Physics of Microstructures (Russian Federation); Yu. Ya. Platonov, Rigaku Americas Corp. (United States); D. N. Rogachev, N. N. Salashchenko, N. I. Chkhalo, Institute for Physics of Microstructures (Russian Federation)

8076 ON Multilayers for next generation EUVL at 6.X nm [8076-22]

Y. Platonov, J. Rodriguez, M. Kriese, Rigaku Innovative Technologies, Inc. (United States);

E. Gullikson, Lawrence Berkeley National Lab. (United States); T. Harada, T. Watanabe,

H. Kinoshita, Univ. of Hyogo (Japan)

807600 Freestanding multilayer films for application as phase retarders and spectral purity filters in the soft x-ray and EUV ranges [8076-23]

N. I. Chkhalo, M. N. Drozdov, S. A. Gusev, E. B. Kluenkov, A. Ya. Lopatin, V. I. Luchin, N. N. Salashchenko, Institute for Physics of Microstructures (Russian Federation); L. A. Shmaenok, PhysTeX (Netherlands); N. N. Tsybin, B. A. Volodin, Institute for Physics of Microstructures (Russian Federation) 
8076 OP Manufacturing and characterization of diffraction quality normal incidence optics for the XEUV range [8076-24]

N. I. Chkhalo, M. M. Barysheva, A. E. Pestov, N. N. Salashchenko, M. N. Toropov, Institute for Physics of Microstructures (Russian Federation)

\section{POSTER SESSION}

8076 OR Performance benchmark of a gateable microchannel plate detector for extreme ultraviolet radiation with high temporal resolution [8076-25]

J. Hauck, R. Freiberger, RWTH Aachen Univ. (Germany); L. Juschkin, RWTH Aachen Univ. (Germany) and Univ. College Dublin (Ireland)

8076 OS The CODEX sounding rocket payload [8076-26]

B. Zeiger, A. Shipley, W. Cash, T. Rogers, Univ. of Colorado at Boulder (United States);

T. Schultz, R. McEntaffer, Univ. of lowa (United States); M. Kaiser, Univ. of Colorado at Boulder (United States)

8076 OT CODEX sounding rocket wire grid collimator design [8076-27]

A. Shipley, B. Zeiger, T. Rogers, Univ. of Colorado at Boulder (United States)

8076 OU Optimization of the MARS-XRD collimator using converging blades [8076-28]

C. Pelliciari, L. Marinangeli, F. Critani, A. Baliva, Univ. d'Annunzio di Pescara (Italy);

I. Hutchinson, Univ. of Leicester (United Kingdom)

Author Index 


\title{
Conference Committee
}

\author{
Symposium Chairs
}

Miroslav Hrabovský, Palacký University Olomouc (Czech Republic)

Wolfgang Sandner, Max-Born-Institut für Nichtlineare Optik und

Kurzzeitspektroskopie (Germany) and Laserlab Europe

Bahaa Saleh, College of Optics and Photonics, University of Central Florida (United States)

Jan Řídký, Institute of Physics, ASCR (Czech Republic)

Symposium Honorary Chair

Jan Peřina, Sr., Palacký University Olomouc (Czech Republic)

Conference Chairs

René Hudec, Astronomical Institute, ASCR (Czech Republic) and Czech Technical University in Prague (Czech Republic)

Ladislav Pina, Czech Technical University in Prague (Czech Republic)

\section{Program Committee}

Webster C. Cash, Jr., University of Colorado at Boulder (United States)

George W. Fraser, University of Leicester (United Kingdom)

Ali M. Khounsary, Argonne National Laboratory (United States)

Alan G. Michette, King's College London (United Kingdom)

Giovanni Pareschi, Osservatorio Astronomico di Brera (Italy)

Yuriy Ya. Platonov, Rigaku Innovative Technologies (United States)

Paul B. Reid, Harvard-Smithsonian Center for Astrophysics (United States)

Bedrich Rus, Institute of Physics, ASCR (Czech Republic)

Anatoly A. Snigirev, European Synchrotron Radiation Facility (France)

Peter Z. Takacs, Brookhaven National Laboratory (United States)

Melville P. Ulmer, Northwestern University (United States)

David L. D. Windt, Reflective X-Ray Optics LLC (United States)

William W. Zhang, NASA Goddard Space Flight Center (United States) 
Downloaded From: https://www.spiedigitallibrary.org/conference-proceedings-of-spie on 25 Apr 2023

Terms of Use: https://www.spiedigitallibrary.org/terms-of-use 


\section{Introduction}

This volume includes the papers presented at the SPIE Europe conference on EUV and X-Ray Optics: Synergy between Laboratory and Space, held in Prague during the SPIE Europe congress in April 2011.

The topic of the conference reflects the success of analogous SPIE conference held in Prague in April 2009 and developments in the Czech Republic over last several decades, and also the growing involvement of European laboratories, Institutes, and companies in both laboratory as well as astronomical x-ray optics.

The development of astronomical imaging grazing incidence $x$-ray optics started in Czechoslovakia 41 years ago and hence has a long tradition. Later on, applications for laboratory started. The first Czech x-ray grazing incidence mirrors were manufactured by electroforming replication technology: based on collaboration with gramophone industry from where the galvanoplastics technology was adopted. Now, Czech institutes and companies still continue to participate in various projects with imaging x-ray optics, from laboratory to astronomical- and space-based, with emphasis on design and development of innovative designs and technologies, as well as cost effective solutions.

The motto of the conference was: synergy between laboratory and space in the field of x-ray optics.

This is, we believe, especially important now, as the future space x-ray astronomy missions such as ATHENA, in consideration by European Space Agency (ESA), require development of completely novel technologies and achieving fine angular resolution; similar requirements are also in the field of synchrotron and laboratory $x$-ray optics. It is obvious that some efforts can be shared among the two x-ray optics communities.

The conference was held about 2.5 years after Czech Republic became a full member of European Space Agency. This means new conditions for Czech Institutes participating in design and development of space x-ray optics.

The response to this conference was large, and we have got numerous contributions (oral and posters) and over 80 participants from Europe, United States, Russia, and other countries. Out of the 29 expected presentations, 25 manuscripts were published: 21 oral and 4 posters.

We thank all who contributed to this fruitful conference.

René Hudec Ladislav PIna 
Downloaded From: https://www.spiedigitallibrary.org/conference-proceedings-of-spie on 25 Apr 2023

Terms of Use: https://www.spiedigitallibrary.org/terms-of-use 